\title{
ANALISIS PENALARAN PROPORSIONAL PADA SISWA KESULITAN BELAJAR MATEMATIKA DI SEKOLAH INKLUSIF
}

\author{
Imam Yuwono ${ }^{1 \S}$, Adelia Ananda Putri ${ }^{2}$ \\ ${ }^{1}$ Pendidikan Khusus, FKIP - Universitas Lambung Mangkurat [Email: imam.plb@ulm.ac.id] \\ ${ }^{2}$ Pendidikan Khusus, FKIP - Universitas Lambung Mangkurat [Email: adelia.plb@gmail.com] \\ ${ }^{\S}$ Corresponding Author
}

\begin{abstract}
Many Mathematical concepts require students to use proportional reasoning. Proportional reasoning can be an indication of the level of students' mastery of mathematics on subjects involving comparison problems. Problems solving with proportional reasoning can be even more challenging for students with mathematic learning disabilities. The purpose of this study was to analyze the reasoning of students of difficulty learning mathematics in inclusive schools. Research approach with qualitative methods. The results showed that the three subjects in solving four different types of problems tended to be the same. Proportional reasoning ability of the three subjects is at level 0 to 1 proportional reasoning ability.
\end{abstract}

Keywords: Proportional Reasoning, Mathematic Learning Disabilities, Inclusive Schools

\section{PENDAHULUAN}

Kemampuan penalaran proporsional adalah kemampuan yang penting dimiliki oleh siswa dalam belajar matematika (Arifah, 2017). Penalaran proporsional mewakili kemampuan berpikir yang komplek tentang ide yang saling terkait, misalnya tentang perkalian. Penalaran proporsional diambil dari kata penalaran atau berpikir secara logis dan proporsional atau situasi perbandingan, sehingga dapat diartikan sebagai berpikir secara logis dalam situasi perbandingan (Nugraha et al., 2016).

Menurut Piaget dalam (Irawati, 2016) penalaran proporsional diartikan sebagai struktur penalaran yang kualitatif, dimana pemahaman memungkingkan bersifat komplek dan mengandung banyak faktor, seperti pemahaman yang berkaitan dengan proposisi atau rasio. Misalnya, diketahui perbandingan antar a dan b adalah 3, a dan c adalah 2. Berapa perbandingan a dan $c$ ? Untuk menjawab pertanyaan ini, proses berpikir anak berada pada penalaran proporsional.

Singkatnya penalaran proporsional adalah cara berpikir yang kompleks tentang ide-ide yang saling berhubungan seperti perkalian dan pembagian pada bilangan bulat, pecahan, rasio, pangkat, pengukuran, dan persen (Hino dan
Kato dalam (Im \& Jitendra, 2020). Dalam pelajaran matematika banyak konsep yang mengharuskan siswa mampu berpikir proporsional (Hajidah, 2017), seperti yang diungkapkan oleh Dolle dkk dikutip dari (Eka \& Susanah, 2013) bahwa materi pecahan, persentasi, rasio, desimal, skala, aljabar, dan peluang membutuhkan penalaran proporsional.

Pada berbagai aspek kehidupan penalaran proporsional seringkali diperlukan, misalnya untuk mempertimbangkan harga barang yang lebih terjangkau dalam membeli sesuatu (Sari \& Mampouw, 2019). Sejalan dengan pendapat Cetin, 2011 dalam bahwa berbagai situasi dalam kehidupan sehari-hari membutuhkan keterampilan berupa penalaran proporsional. Menurut pendapat Walle dalam (Nugraha et al., 2016) pada kehidupan sehari-hari, banyak sekali permasalahan mengenai situasi proporsional, di antaranya yaitu perbandingan dalam penetapan harga, penggunaan skala dalam peta, penyelesaian persoalan tentang persentase, penggunaan skala dalam merancang suatu bangunan, dan masih banyak lagi.

Pada dasarnya kemampuan penalaran siswa berbeda dengan siswa yang lainnya, tetapi kemampuan penalaran siswa saat memecahkan permasalahan matematika sangat penting dan dapat dilakukan melalui berbagai cara penyelesaian (Fatmaningrum, n.d.). 
Namun menyelesaikan masalah dengan penalaran proporsional dapat menjadi lebih menantang bagi siswa kesulitan belajar Matematika (American Psychiatric Association dalam (Im \& Jitendra, 2020). Menurut Putri dalam (Arisandi, 2014) kesulitan belajar Matematika menyebabkan siswa menjadi tidak bisa berhitung. Kesulitan belajar merupakan gangguan yang nampak terlihat pada anak berkaitan tugas umum maupun khusus, bisa difaktori oleh disfungsi neurologis, proses psikologis maupun sebab lain sehingga membuat menunjukkan prestasi belajar anak rendah (Masroza, 2013).

Siswa kesulitan belajar Matematika sering tidak memiliki keterampilan aritmatika dasar. Tentu saja mereka mengalami masalah ketika mempelajari Matematika, terlebih lagi jika siswa tersebut berada di sekolah inklusi (Lastaria \& Istiqlaliyah, 2019). Siswa kesulitan belajar cenderung mendapat perlakuan yang sama dengan siswa reguler pada umumnya, artinya pembelajaran atau pelayanan pendidikan yang diberikan disamaratakan dengan yang tidak mengalami kesulitan belajar (Irawati, 2016). Hal itu dikarenakan guru dalam melakukan kegiatan belajar mengajar mengacu pada kurikulum yang digunakan oleh sekolah dan tidak beradaptasi dengan kebutuhan peserta didik dengan kebutuhan khusus (Yuwono, Utomo, et al., 2018). Padahal pada hakikatnya pendidikan inklusif sebagai bentuk kepedulian terhadap pemerataan dan pengembangan pendidikan yang berkualitas, melalui sistem pendidikan inklusif diharapkan dapat mengakomodasi kebutuhan pendidikan masyarakat (Yuwono et al., 2017).

Mengingat penalaran proporsional merupakan aktivitas yang tidak dapat dipisahkan dalam belajar Matematika (Sari \& Mampouw, 2019), peneliti tertarik untuk mengetahui penalaran proporsional siswa kesulitan belajar matematika di sekolah inklusi pada jenjang SMP. Hal ini dikarenakan secara umum siswa pada jenjang SMP memiliki kisaran usia antara 13 hingga 16 tahun. Menurut teori perkembangan kognitif Piaget dikutip dari (Permatasari, 2017), anak-anak pada kisaran usia tersebut berada pada tahapan operasi formal. Pada tahapan ini, pemikiran anak berkembang dan anak sanggup berpikir abstrak dan logis. Oleh karena itu, pada penelitian ini peneliti menganalisis penalaran proporsional pada siswa kesulitan belajar Matematika di SMP inklusif.

\section{METODE PENELITIAN}

Metode pada penelitian ini yaitu deskriptif dan pendekatan kualitatif_yang memaparkan hasil penelitian berupa analisis tentang kemampuan penalaran proporsional siswa kesulitan belajar matematika (SKBM) di SMP Inklusif di Banjarmasin. Subjek penelitian merupakan siswa kelas VIII tahun pelajaran 2019/2020. Pemilihan subjek diperoleh dari hasil tes kemampuan Matematika (TKM) serta berdasarkan rekomendasi guru sehingga terpilih 3 orang subjek. Kemudian diberikan inisial A, $\mathrm{R}, \mathrm{G}$ pada kategori berkemampuan matematika rendah.

Teknik pengumpulan data digunakan teknik tes tulis dan wawancara. Instrumen dalam penelitian ini terdiri dari peneliti sendiri sebagai instrumen utama dan didukung oleh instrumen yang terdiri dari soal tes matematika (TM), Tugas Penalaran Proporsional (TPP), dan Pedoman Wawancara (PW). yang bersifat konfirmasi terhadap jawaban subjek pada TPP. Selanjutnya, analisis data dalam penelitian ini berisikan Analisis Data Tugas Penalaran Proporsional (TPP) dan Wawancara. Analisis data TPP dan wawancara mengacu pada komponen penalaran proporsional siswa. Analisis data TPP dan wawancara ini dilakukan untuk melihat penalaran proporsional siswa ke dalam level penalaran proporsional dari level rendah (1), hingga meningkat ke level berikutnya (2,3 dan seterusnya). Langkahlangkah hasil tes dan wawancara dianalisis menggunakan langkah Miles \& Huberman dalam (Lewis, 2012) yaitu yang pertama reduksi data, kedua penyajian data, dan terakhir penarikan kesimpulan.

\section{HASIL DAN PEMBAHASAN}

\subsection{Skor kemampuan penalaran proporsional}

Rekapitulasi kemampuan penalaran proporsional dari Subjek A, R, dan G dalam memecahkan matematika yang terdiri dari 4 tipe masalah ditampilkan pada tabel berikut:

Tabel 1. Hasil Rekapitulasi Penalaran Subjek

\begin{tabular}{|l|c|c|c|}
\hline \multirow{2}{*}{\multicolumn{1}{c|}{ Tipe Soal }} & \multicolumn{3}{|c|}{ Level Penalaran } \\
\cline { 2 - 4 } & $\mathrm{A}$ & $\mathrm{R}$ & $\mathrm{G}$ \\
\hline Part-Part Whole & 1 & 2 & 2 \\
\hline Associated Sets & 1 & 2 & 1 \\
\hline Well-Known Measures & 1 & 1 & 1 \\
\hline Growth & 1 & 1 & 1 \\
\hline
\end{tabular}




\subsection{Kemampuan Penalaran Subjek dalam Memecahkan Masalah Matematika Tipe Part-Part Whole}

Subjek A dalam mengerjakan tipe soal kualitatif dimulai dengan menggambar untuk menyatakan bahwa dalam 1 kantong terdapat 5 kelereng, 2 diantaranya berwarna pink dan 3 berwarna merah. Hal ini menunjukkan bahwa subjek mengetahui informasi yang terdapat pada soal. Subjek menggunakan proses mengkolaborasikan informasi pada soal untuk menemukan banyaknya kantong dengan cara membagi total kelereng dengan jumlah kelereng dalam 1 kantong. Subjek menggambarkan banyaknya kantong yang telah ditemukan dan menuliskan pada masingmasing kantong terdapat 2 kelereng pink dan 3 kelereng merah. Subjek menghitung banyaknya kelereng pink dan kelereng merah untuk menyimpulkan jawabannya. Subjek menceritakan proses tersebut sebagai berikut: "Saya membagi 25 kelereng. Dalam 1 kantong terdapat 5 kelereng. Jadi ada 5 kantong. Kemudian saya gambar. Manualnya saya gambar. Ini kan ada 5 kantong, kemudian pinknya ada 2. (membaca dan menunjuk angka 2 sebanyak 5 kali) 2 dikali 5 itu 10. Setelah ini yang 3 ini, 3 dikali 5 itu 15 begitu".

Berdasarkan jawaban lisan maupun tertulis, kemampuan penalaran proporsional subjek A dalam memecahkan masalah yang menyatakan subset keseluruhan dibandingkan dengan komplemennya (part-part whole) dapat mencapai strategi penalaran proporsional level 1. Pada level ini subjek menunjukkan ciri dengan cenderung menggunakan gambar untuk memahami masalah yang terdapat pada soal.

Subjek R mula-mula menuliskan apa yang diketahui pada soal yaitu jumlah seluruh kelereng dan jumlah kelereng dalam setiap kantong. Subjek mulai mencari banyaknya kantong dengan membagi total kelereng dengan jumlah kelereng dalam setiap kantong Subjek menuliskan $\frac{2}{5}$ yang artinya terdapat 2 kelereng pink dari 5 kelereng serta menuliskan $\frac{3}{5}$ untuk kelereng merah. Banyaknya kantong yang ditemukan kemudian dikalikan dengan banyaknya kelereng berwarna pink untuk mengetahui total kelereng pink, begitu pun dalam mencari total kelereng merah. Strategi ini merupakan cara menghubungkan model melalui perhitungan numerik dan menggunakan unit komposit. Subjek menceritakan proses tersebut sebagai berikut: "Nah setiap kantong berisi 5 kelereng. Saya mencari berapa jumlah kantongnya terlebih dahulu. Dari 25 ini dibagi 5, ditemukan 5 kantong. Setiap kantong itu berisi 2 warna pink dan 3 warna merah, tinggal dikalikan. Kelereng merah yang jumlahnya 3 setiap kantong dikalikan 5. Jadi hasilnya 15 kelereng. Sedangkan kelereng pink itu 2 dikalikan 5. Jadi hasilnya 10 kelereng".

Berdasarkan jawaban lisan maupun tertulis, kemampuan penalaran proporsional subjek $\mathrm{R}$ dalam memecahkan masalah yang menyatakan subset keseluruhan dibandingkan dengan komplemennya (part-part whole) dapat mencapai strategi penalaran proporsional level 2. Pada level ini subjek menunjukkan strategi pemecahan masalah dengan menghubungkan model melalui perhitungan numerik dan menggunakan unit komposit.

Jawaban subjek $\mathrm{G}$ dalam mengerjakan tipe soal part-part whole hampir sama dengan jawaban subjek R. Perbedaannya, subjek M mengetahui hubungan dari 2 variabel yang saling terkait. Apabila banyaknya kelereng pink telah ditemukan, subjek dapat dengan mudah menemukan banyaknya kelereng merah dengan cara mengurangi seluruh kelereng dengan banyaknya kelereng pink. Oleh karena itu kemampuan penalaran proporsional subjek $G$ dalam memecahkan masalah yang menyatakan subset keseluruhan dibandingkan dengan komplemennya (part-partwhole) dapat mencapai strategi penalaran proporsional level 2 (dua)

\subsection{Kemampuan Penalaran Subjek dalam Memecahkan Masalah Matematika Tipe Associated Sets}

Jawaban Subjek A dimulai dengan menggambar dua lingkaran sebagai donat dan menuliskan diameter didalamnya. Subjek kemudian menuliskan rumus $\pi \mathrm{x}$ d sebagai rumus luas lingkaran. Meskipun kurang tepat dalam mengingat rumus luas lingkaran, namun subjek A mampu membuat perbandingan kualitatif bahwa untuk mengetahui nilai jual donat tersebut dengan melihat hubungan luas dan harganya. Subjek menyimpulkan nilai donat yang lebih murah dari hasil luas dan harga donat dengan membandingkannya secara langsung melalui penalaran. Subjek A menggunakan rumus luas $\pi x d$. Alasan dalam menggunakan rumus luas dinyatakan sebagai berikut: "Karena yang dicari itu apanya, 
permukaannya. Kalau menurut saya, permukaannya dicari, kemudian nanti bisa ditentukan dari harganya. Kalau permukaannya besar, kemudian harganya kecil kan itu untung".

Berdasarkan jawaban lisan maupun tertulis, kemampuan penalaran proporsional subjek A dalam memecahkan masalah yang menyatakan hubungan dua kuantitas yang biasanya tidak terkait melalui konteks masalah (assosiated sets) dapat mencapai strategi penalaran proporsional level 1. Pada level ini subjek menunjukkan strategi pemecahan masalah dengan menggunakan gambar untuk mempermudah menjawab soal dan mampu membuat perbandingan kualitatif.

Subjek $\mathrm{R}$ membandingkan kedua donat secara langsung dari diameter dan harganya. Donat kecil dengan diameter $10 \mathrm{~cm}$ dan harga Rp10.000 dibandingkan dengan donat besar dengan diameter $20 \mathrm{~cm}$ dan harga Rp20.000 sehingga didapatkan perbandingan $1: 1$. Dari hasil tersebut, subjek menyimpulkan perbandingan kedua donat bernilai sama. Dalam hal ini subjek $\mathrm{R}$ mampu menggunakan penalaran kuantitatif namun kurang memperhatikan bahwa ukuran donat jika diameternya diperbesar maka perubahannya tidak konstan sehingga seharusnya perbandingan itu tidak dapat digunakan secara langsung. Subjek $\mathrm{R}$ menceritakan proses tersebut sebagai berikut: "Ini donatnya bernilai sama karena perbandingan kedua diameter dan harganya sama. Ini kan $10 \mathrm{~cm}$ dibandingkan dengan Rp10.000 dan 20 cm dengan Rp20.000, diperoleh 1 banding 1 . Jadi perbandingannya sama”. Berdasarkan jawaban lisan maupun tertulis, kemampuan penalaran proporsional subjek $\mathrm{R}$ dalam memecahkan masalah yang menyatakan hubungan dua kuantitas yang biasanya tidak terkait melalui konteks masalah (assosiated sets) dapat mencapai strategi penalaran proporsional level 2. Pada level ini subjek menunjukkan strategi pemecahan masalah menggunakan penalaran kuantitatif. Jawaban subjek $\mathrm{G}$ hampir sama dengan subyek A yaitu menggunakan gambar ilustrasi gambar lingkaran yang lebih besar dan lebih kecil. "Karena yang dicari itu lebarnya. Kalau menurut saya, permukaannya diperhatikan lalu ditentukan dari harganya. Kalau permukaannya besar, kemudian harganya kecil kan itu untung".

Berdasarkan jawaban lisan maupun tertulis, kemampuan penalaran proporsional subjek $\mathrm{G}$ dalam memecahkan masalah yang menyatakan hubungan dua kuantitas yang biasanya tidak terkait melalui konteks masalah (assosiated sets) dapat mencapai strategi penalaran proporsional level 1. Pada level ini subjek menunjukkan strategi pemecahan masalah dengan menggunakan gambar untuk mempermudah menjawab soal tapi tidak dapat menghubungkan kedua ukuran.

\subsection{Kemampuan Penalaran Subjek dalam Memecahkan Masalah Matematika Tipe Well-Known Measures}

Subjek A menuliskan 3 opsi dan memisalkan opsi ketiga sebagai opsi C. Pada opsi A subjek menuliskan 1 bulan dengan biaya Rp20.000 yang diperoleh dari jumlah pembayaran dikali dengan harga per pembayaran, begitu pun untuk opsi B dan opsi C. Subjek menyimpulkan opsi B lebih baik dari opsi A dengan cara mencari jarak antara penawaran banyaknya bulan pada kedua opsi tersebut. Selain itu subjek juga mencari selisih harga dari kedua opsi yang ditawarkan. Subjek membuat hubungan antara bulan dengan bulan dan rupiah dengan rupiah, namun tidak mementingkan hubungan bulan dengan rupiah. Hal ini menunjukkan bahwa subjek menggunakan penalaran dalam keputusannya dengan menyimpulkan secara langsung dari perbandingan yang ia temukan. Subjek A menceritakan proses tersebut sebagai berikut: "Oh iya, opsi B lebih baik dari opsi A karena 1 bulan dengan 3 bulan hanya berjarak 2 bulan dan pembayarannya selisih hanya Rp20.000. Itu sangat tanggung menurut saya". Penjelasan mengenai opsi $\mathrm{C}$ dinyatakan sebagai berikut: "Menurut saya jawaban disini opsi A lebih baik dari opsi $\mathrm{C}$ karena jarak bulannya kan 8 bulan dan pembayarannya pun selisihnya banyak". Jawaban subjek juga tertuju pada hubungan opsi C dengan opsi B ketika yang ditanyakan adalah opsi $\mathrm{C}$ dengan opsi A. Namun dalam hal ini, yang diperhatikan adalah bagaimana subjek memutuskan opsi yang lebih baik dari hubungan bulan dengan rupiah.

Berdasarkan jawaban lisan maupun tulisan, kemampuan penalaran proporsional subjek A dalam memecahkan masalah yang menyatakan hubungan yang dikenal entitas atau tarif (well-known measures) dapat mencapai strategi penalaran proporsional level 1. Pada level ini subjek menunjukkan strategi pemecahan masalah menggunakan penalaran 
kualitatif serta menyimpulkan secara langsung dari perbandingan yang ia temukan.

Jawaban subjek $G$ dan subjek $R$ hampir sama, yatu mereka menuliskan beberapa opsi tanpa bisa menjelaskan alasan pemilihan opsi tersebut. Berdasarkan jawaban lisan maupun tertulis, kemampuan penalaran proporsional subjek $\mathrm{G}$ dan $\mathrm{R}$ dalam memecahkan masalah yang menyatakan hubungan yang dikenal entitas atau tarif (well-known measures) dapat mencapai strategi penalaran proporsional level 1 karena tidak dapat mengenali hubungan perkalian.

\subsection{Kemampuan Penalaran Subjek dalam Memecahkan Masalah Matematika Tipe Growth}

Subjek G menggunakan operasi pengurangan untuk mengetahui perubahan kedua ukuran. Subjek mencari selisih tinggi kedua gajah sebelum dan setelah 2 tahun sehingga menemukan bahwa pertumbuhan panjang keduanya sama yaitu 2 meter. Berdasarkan perspektif aditif, respon ini benar bahwa pertumbuhan kedua gajah sama yaitu 2 meter. Namun subjek tidak mengetahui bahwa pada pandangan multiplikatif, pertumbuhan keduanya berbeda. Pada masalah ini, subjek mampu menggambarkan situasi perubahan dalam pandangan aditif saja, tidak untuk multiplikatif. Subjek G menceritakan proses tersebut sebagai berikut: "Saya kurang saja tinggi Bona dan Bonbon. Kan Bona awalnya 1 meter menjadi 3 meter. Kalau Bonbon awalnya 2 meter menjadi 4 meter, kalau dikurangkurangi itu semua sama, tambahnya itu 2 meter semua”. Berdasarkan jawaban lisan maupun tertulis, kemampuan penalaran proporsional subjek $\mathrm{G}$ dalam memecahkan masalah yang menyatakan hubungan antara dua kuantitas yang terus menerus dan melibatkan peningkatan skala (growth) dapat mencapai strategi penalaran proporsional level 1. Pada level ini subjek menunjukkan strategi pemecahan masalah dengan menggambarkan situasi perubahan dalam pandangan aditif saja, tidak untuk multiplikatif.

Jawaban Subjek A dan subjek R hampir sama dengan subjek G. Perbedaannya, subjek A menambahkan pada jawabannya bahwa setiap 2 tahun pertumbuhan mereka dapat diperkirakan sama. Subjek A juga menuliskan panjang kedua buaya setelah 5 tahun dengan pertumbuhan yang sama. Sedangkan subjek $\mathrm{R}$ menjelaskan bahwa perubahan kedua ukuran terjadi karena menambahkan ukuran yang sama. Oleh karena itu kemampuan penalaran proporsional subjek A dan $\mathrm{R}$ dalam memecahkan masalah yang menyatakan hubungan antara dua kuantitas yang terus menerus dan melibatkan peningkatan skala (growth) dapat mencapai strategi penalaran proporsional level 1.

\subsection{Pembahasan}

Berdasarkan data hasil observasi, peneliti melihat siswa kesulitan belajar Matematika kurang mampu memahami permasalahan yang terkandung dalam soal matematika. Mereka ada yang mampu menuliskan yang diketahui dan ditanyakan dalam soal. Tetapi tidak dapat melanjutkan ke tahap penyelesaian yaitu dengan memilih dan menentukan variabel yang dapat digunakan untuk menyelesaikan masalah. Siswa tidak mampu mengubah ke dalam bentuk aljabar, mereka menjawab soal dengan menggunakan gambar. Selanjutnya siswa melaksanakan rencana penyelesaian tersebut yaitu melakukan operasi hitung. Langkah terakhir siswa mengecek kembali soal dan jawaban dengan memberikan kesimpulan dari soal tersebut. Menurut Sumardyono, 2007 mengemukakan ada empat tahapan pokok pemecahan masalah bersumber dari buku George Polya tahun 1945 berjudul "How To Solve It". Keempat langkahnya yaitu mengerti soal atau masalah pada soal selengkap mungkin, menentukan penyelesaian dari beberapa alternatif yang memungkinkan, menerapkan rencana tadi dengan tepat, cermat dan benar, kemudian memeriksa jawaban apakah sudah benar, lengkap, jelas dan argumentatif (beralasan). Namun pada ketiga subjek masih belum mampu melakukan keempat langkah tersebut.

Pada pemecahan masalah part-part whole, subjek A menunjukkan kemampuan penalaran proporsional pada level 1 dengan cenderung menggunakan gambar untuk mengetahui situasi yang terdapat pada soal. Syahlan, 2017 menyatakan bahwa siswa terkadang perlu untuk mempresentasikan permasalahan Matematika kedalam bentuk gambar untuk mengetahui apa yang harus diselesaikan. Sedangkan subjek R dan subjek $G$ menunjukkan kemampuan penalaran proporsional pada level 2 dengan menghubungkan model melalui perhitungan numerik dan menggunakan unit komposit. Meskipun ketiga subjek belum mencapai level 
penalaran proporsional tinggi, namun ketiga subjek telah mengetahui konsep penalaran proporsional dengan mencapai level 1 (penalaran informal tentang situasi proporsional) dan level 2 (penalaran kuantitatif).

Pada pemecahan masalah associated sets, proses penalaran proporsional ketiga subjek berbeda-beda. Subjek A menunjukkan kemampuan penalaran proporsional pada level 1 dengan membuat perbandingan kualitatif dan menggunakan gambar untuk mempermudah menjawab soal. Subjek $\mathrm{R}$ menunjukkan kemampuan penalaran proporsional pada level 2 dengan menggunakan penalaran kuantitatif. Sedangkan subjek $\mathrm{G}$ menunjukkan kemampuan penalaran proporsional pada level 1 menjawab menggunakan gambar tapi tidak dapat menghubungkan kedua ukuran. Nabors (dalam Prayitno et al., 2018) menyatakan bahwa proses penalaran proporsional siswa berbeda-beda karena kemampuan penalaran proporsional mereka juga berbeda. Pada pemecahan masalah well-known measures, subjek A menunjukkan kemampuan penalaran proporsional pada level 1 dengan membuat perbandingan kualitatif dan menyimpulkan secara langsung dari perbandingan yang ia temukan. Subjek R dan G menunjukkan kemampuan penalaran proporsional yang dikategorikan level 1 karena kedua subjek tidak dapat mengenali hubungan perkalian.

Pada pemecahan masalah growth, ketiga subjek menunjukkan kemampuan penalaran proporsional pada level 1 dengan menggambarkan situasi perubahan dalam pandangan aditif. Dalam hal ini, masalah growth yang diberikan memungkinkan jawaban dengan menggunakan strategi aditif dan multiplikatif. Walle (dalam Sari \& Mampouw, 2019) menyatakan bahwa kemampuan memahami perbedaan antara situasi aditif dan multiplikatif merupakan indikasi dari penalaran proporsional. Namun pada masalah ini ketiga subjek hanya mengetahui strategi aditif, tidak untuk multiplikatif. Seperti pada penelitian (Parish, 2010) bahwa sebagian besar siswanya tidak mahir dengan fakta multiplikasi mereka.

Norton, 2005 menyebutkan bahwa pengguaan operasi perkalian dan pembagian untuk menyelesaikan masalah yang melibatkan situasi proporsional belum tentu mengembangkan pemahaman yang lebih dalam penalaran proporsional. Hal ini diperkuat dengan pernyatan (Park et al., 2010) yang menyatakan bahwa "an area identified as a problem type for which students not having learned a formal proportional expression cannot under- stand the multiplicative relationship very well".

Ketika siswa dihadapkan pada suatu bentuk perbandingan, ternyata siswa mengacu pada soal yang diberikan. Hal ini terlihat ketika siswa hanya mengetahui bentuk perbandingan dengan menggunakan rasio dalam (within ratio), tetapi tidak mengetahui bentuk perbandingan menggunakan rasio antara (between ratio). Hal yang sama juga diungkapkan oleh (Walle, 2008), dimana kesulitan terbesar siswa adalah membuat sebuah perbandingan yang benar dari dua rasio, salah satunya mencakup nilai yang belum diketahui. Dengan demikian, dapat dikatakan bahwa siswa tidak sepenuhnya memahami hubungan invarian dan kovarian.

Hal yang menarik pada penelitian ini yaitu ketiga siswa selalu menggunakan bantuan media gambar dalam memanipulasi situasi perbandingan yang dihadapi. Hal ini sejalan dengan pendapat DeCorte dkk (dalam Nunokawa, 2012), penggunaan media gambar sangat membantu dalam merubah pemahaman informal menjadi formal. Pada saat menggunakan tabel, secara tidak langsung siswa bisa menggunakan media gambar, karena angka-angka yang terdapat di tabel ternyata merupakan representasi dari media gambar. Media gambar digunakan dengan tujuan menanamkan konsep awal mengenai perbandingan sebelum dikenalkan pada prosedur algoritmis. Hal menarik lainnya yaitu ketika siswa sudah mengetahui mengenai bentuk perbandingan, tetapi tidak menggunakan bentuk perbandingan tersebut dalam memecahkan masalah dan lebih cenderung menggunakan stategi informal untuk memecahkan masalah perbandingan. Vincent, 2009 mengungkapkan bahwa, siswa melakukan beberapa pengandaian dalam bernalar dan tidak mesti menggunakan algoritma yang sudah diketahui.

Berdasarkan wawancara peneliti dengan masing-masing subjek, strategi penyelesaian soal yang digunakan oleh siswa menunjukkan bahwa mereka kurang memahami dan mengerti dasar konseptualnya. Siswa kurang mengerti konsep aritmatika dan untuk bernalar secara proporsional. Seperti yang dijelaskan oleh (Arvyaty \& Saputra, 2017) bahwa kemampuan penalaran proporsional dapat menunjukkan 
tinggi rendahnya penguasaan Matematika siswa pada pokok bahasan yang melibatkan masalah penalaran proporsional.

Pada penelitian yang dilakukan oleh (Im \& Jitendra, 2020) menunjukkan bahwa secara khusus kesalahan dan kesalahpahaman pada siswa dengan kesulitan belajar Matematika dijabarkan lebih jelas sebagai berikut: (a) Siswa dengan MLD (Mathematic Learning Disability) tidak tahu bagaimana mengekspresikan rasio sebagai notasi fraksional, (b) ketika siswa dengan MLD tidak mengidentifikasi jenis rasio (bagian-ke-bagian atau bagian-ke-whole ratio), dan (c) ketika masalah diperlukan konversi rasio menjadi persen atau memerlukan beberapa langkah.

Hasil tersebut menujukkan terdapat siswa berisiko mengalami kesulitan belajar Matematika (diskalkulia) pada setiap kelasnya. Kesulitan yang dialami siswa ialah kesulitan terhadap pemahaman dalam melakukan perhitungan secara sistematis. Siswa juga mengalami kesulitan dalam memahami dalam konsep aturan, rumus, dan urutan. Terkadang siswa juga sulit dalam memperkirakan waktu, arah, urutan, pemahaman angka (pecahan, bilangat bulat, desimal, dan persen), dan sangat buruk ingatan jangka panjang siswa tentang sebuah konsep Matematika.

Pernyataan diatas sesuai dengan pendapat LDAAmerica (2013) dalam (Adhim, 2019), juga menyatakan bahwa diskalkulia mempengaruhi kemampuan seseorang untuk memahami angka dan mempelajari fakta Matematika. Orang-orang dengan ketidakmampuan belajar jenis ini mungkin juga memiliki pemahaman yang buruk tentang simbol-simbol matematika, kesulitan dalam menghafal dan mengatur angka-angka, mengalami kesulitan dalam menentukan waktu, atau kesulitan dalam menghitung. Serta pendapat Department for Education and Skills (DfES) (dalam Butterworth, 2003), bahwa diskalkulia merupakan suatu kondisi yang mempengaruhi kemampuan untuk memperoleh keterampilan aritmatika. Siswa yang mengalami diskalkulia mungkin mengalami kesulitan memahami hal yang sederhana seperti konsep angka, tidak memiliki pemahaman angka yang intuitif, dan memiliki masalah dalam mempelajari fakta dan prosedur angka. Bahkan jika mereka menghasilkan jawaban yang benar atau menggunakan metode yang benar, mereka dapat melakukannya secara mekanis dan tanpa adanya keyakinan.
Berdasarkan data yang diperoleh dari hasil observasi dan wawancara peneliti dengan masing-masing subjek, strategi yang diterapkan oleh ketiga subjek hampir sama. Meskipun ketiga siswa menggunakan strategi yang sama, tetapi ketika diwawancarai terdapat satu siswa yang menjawab berbeda dengan yang lainnya. Seperti yang diungkapkan oleh (Eka \& Susanah, 2013) bahwa untuk menilai penalaran proporsional siswa tidak hanya berdasarkan pada strategi siswa dalam menyelesaikan masalah. Siswa yang dalam menyelesaikan masalah menggunakan strategi yang sama belum tentu memiliki kemampuan penalaran proporsional yang sama juga.

Tujuan analisis proporsional pada siswa dengan kesulitan belajar karena agar dapat mengidentifikasi kemampuan penalarannya dalam Matematika sehingga dapat meningkatkan kemampuan anak untuk mencapai prestasi akademis, mencegah munculnya rasa rendah diri dan masalah perilaku lainnya yang dapat mengganggu proses belajar individu (Iftayani \& Ratnaningsih, n.d.). Tarjiah, 2015 menyebutkan bahwa dalam melakukan pelayanan pendidikan guru harus membedakan antara pelayanan bagi siswa berkesulitan belajar dengan siswa pada umumnya, sehingga implementasi pendidikan inklusif akan tercapai. Pembelajaran akan bermakna jika pembelajaran dan pengajaran berdasarkan pada kebutuhan individu serta program pendidikan dikembangkan sesuai keberagaman dan kebutuhan siswa (Yuwono, Rapisa, et al., 2018).

\section{KESIMPULAN DAN SARAN}

Berdasarkan uraian pada hasil dan pembahasan, berikut diberikan kesimpulan dan saran sehubungan dengan penelitian.

\subsection{Kesimpulan}

Secara umum ketiga subjek kurang mampu memahami masalah pada soal dan tidak dapat menyusun rencana penyelesaian dengan memilih dan menentukan variabel yang dapat digunakan untuk menyelesaikan masalah. Siswa melaksanakan penyelesaian permasalahan dengan melakukan operasi hitung sederhana. Kemampuan penalaran proporsional Subjek A cenderung berada pada level 1. Pada tipe soal part-part whole berada pada level 1 yaitu memecahkan masalah dengan menggunakan gambar, begitupun pada tipe soal 
associated sets dan ditambah dengan perbandingan kualitatif. Pada tipe soal wellknown measures berada pada kemampuan level 1 menjawab dengan penlaran kualitatif dan dapat menyimpulkan perbandingan. Kemampuan penalaran proporsional Subjek R cenderung pada level 2 tetapi hanya pada tipe soal part-part whole dan associated sets dimana subjek $\mathrm{R}$ dapat menghubungkan perhitungan numerik dengan uni komposit dan menggunakan penalaran kuantitatif. Kemampuan penalaran proporsional subjek $\mathrm{G}$ cenderung berada pada level 0 . Namun pada tipe soal part-part whole subjek $\mathrm{G}$ dapat menghubungkan perhitungan numerik dan unit komposit sehingga menunjukkan kemampuan penalaran pada level 2. Untuk tipe soal wellknown measures subjek $\mathrm{R}$ dan $\mathrm{G}$ tidak dapat mengenali hubungan perkalian sehingga dikategorikan penalaran pada level 0. Terakhir pada tipe soal growth ketiga subjek tidak dapat memecahkan masalah, subjek hanya menggambarkan situasi perubahan dalam pandangan aditif.

\subsection{Saran}

Mengingat bahwa penalaran proporsional sebagai salah satu tipe dasar berpikir matematis yang berguna dalam kehidupan, maka hendaknya guru dapat memperhatikan tingkat kemampuan penalaran proporsional siswanya. Sebaiknya guru dapat membantu siswa untuk mengembangkan kemampuan penalaran proporsional mereka terlebih kepada siswa kesulitan belajar Matematika. Dengan melalui pengembangan program pembelajaran individual yang berdasar kepada hambatan dan kebutuhan mereka. Disarankan kepada peniliti selanjutnya dapat melakukan penelitian terhadap program pembelajaran Matematika dalam pengembangan kemampuan penalaran proporsional siswa kesulitan belajar Matematika.

\section{DAFTAR PUSTAKA}

Adhim, J. B. (2019). Identifikasi Anak Kesulitan Belajar Matematika (Diskalkulia) di Sekolah Dasar. In Universitas Negeri Surabaya. Universitas Negeri Surabaya.

Arifah, N. (2017). Deskripsi Kemampuan Penalaran Proporsional Matematis Siswa Kelas VII Smp Negeri 1 Kembaran Ditinjau Dari Gaya Kognitif Field-
Dependent Dan Field-Independent. In Skripsi.

Arisandi, E. (2014). Meningkatkan Kemampuan Operasi Perkalian Untuk Anak Diskalkulia Melalui Metode Garismatika. Jurnal Ilmiah Pendidikan Khusus, 3(September), 478-488.

Arvyaty, \& Saputra, C. (2017). Pengaruh Model Pembelajaran Berbasis Masalah (PBM) Terhadap Kemampuan Penalaran Proporsional Siswa Sekolah Menengah Pertama. Jurnal Pendidikan Matematika, 4(1), 62-73.

Butterworth, B. (2003). Dyscalculia screener. 74.

Cetin, H. (2011). The Relationship between Eighth Grade Primary School Students' Proportional Reasoning Skills and Success in Solving Equations. International Journal of Instruction, 4(1), 47-62.

Eka, R., \& Susanah. (2013). Penalaran Proporsional Siswa Kelas VII SMP Negeri II Beji Pasuruan Berdasarkan Tingkat Kemampuan Matematika. Jurnal Pendidikan Matematika, 2(1), 15-21.

Fatmaningrum, D. U. (n.d.). menyelesaikan soal matematika siswa kelas viii smp. 216221.

Hajidah, R. (2017). analisis kemampuan penalaran proporsional siswa kelas vii pada materi perbandingan. Universitas Islam Negeri (UIN) Syarif Hidayatullah.

Iftayani, I., \& Ratnaningsih, A. (n.d.). Profil Kesulitan Belajar Matematika Dan Kecenderungan Diskalkulia Pada Siswa Sekolah Dasar Di Purworejo. 3, 41-52.

Im, S.-, \& Jitendra, A. K. (2020). Analysis of proportional reasoning and misconceptions among students with mathematical learning disabilities. Journal of Mathematical Behavior, 57(March 2019), 1-20. https://doi.org/10.1016/j.jmathb.2019.1007 53

Irawati, T. N. (2016). Pengembangan Paket Tes Kemampuan Penalaran Proposional Siswa SMP.

Lastaria, \& Istiqlaliyah. (2019). Problematika Guru dalam Pembelajaran Matematika pada Pendidikan Inklusi. Jurnal Hadratul 
Madaniyah, 6(I), 10-23.

Lewis, E. T. (2012). Qualitative Data Analysis: a Participatory View (Issue February).

Masroza, F. (2013). Prevalensi anak berkesulitan belajar di sekolah dasar se Kecamatan Pauh Padang. Jurnal Ilmiah Pendidikan Khusus, 1(1), 215-227.

Norton, S. J. (2005). The Construction of Proportional Reasoning. Proceedings of the 29th Conference of the International Group for the Psychology of Mathematics Education, 4, 17-24.

Novita Irawati, T. (2015). Mengembangkan Kemampuan Guru Matematika Dalam Membuat Soal Penalaran Proporsional Siswa SMP. Seminar Nasional Matematika Dan Pendidikan Matematika, 2008, 11011106.

Nugraha, Y., Sujadi, I., \& Pangadi, P. (2016). Penalaran Proporsional Siswa Kelas VII. Beta Jurnal Tadris Matematika, 9(1), 34. https://doi.org/10.20414/betajtm.v9i1.2

Nugroho, I. A. (2014). Analisis,Jenis, Letak Dan Faktor Penyebab Kesulitan Belajar Siswapada Pokok Bahasan Operasi Hitung Aljabarkelas VIII SMP Negeri 3 Kalimanat melalui Tes Diagnostik Tahun 2013/2014. 6-22.

Nunokawa, K. (2012). Multi-relation strategy in students' use of a representation for proportional reasoning. Eurasia Journal of Mathematics, Science and Technology Education, 8(4), 233-248. https://doi.org/10.12973/eurasia.2012.842a

Parish, L. (2010). Facilitating the Development of Proportional Reasoning through Teaching Ratio. Mathematics Education Research Group of Australasia, 469-476. http://www.eric.ed.gov/ERICWebPortal/rec ordDetail?accno=ED520962

Park, J. S., Jee, H. P., \& Oh, N. K. (2010). Characterizing the Proportional Reasoning of Middle School Students. The SNU Journal Of Education Research, 119-144.

Permatasari, D. I. (2017). Penalaran Proporsional Siswa SMP Kelas IX dalam Menyelesaikan Masalah Matematika ditinjau dari Gender. Kreano, Jurnal Matematika Kreatif-Inovatif, 8(2), 199207. https://doi.org/10.15294/kreano.v8i2.9537

Prayitno, A., Rossa, A., Widayanti, F. D., Rahayuningsih, S., Hamid, A., \& Baidawi, M. (2018). Characteristics of Students' Proportional Reasoning in Solving Missing Value Problem. Journal of Physics: Conference Series, 1114(1). https://doi.org/10.1088/1742$6596 / 1114 / 1 / 012021$

Sari, D. N., \& Mampouw, H. L. (2019). Analisis Kemampuan Penalaran Proporsional Siswa Sma Dalam Memecahkan Masalah Matematika. Jurnal Pendidikan Matematika, 5(2), 110-122.

Sumardyono. (2007). pengertian dasar problem solving. 1-29.

Syahlan. (2017). Sepuluh Strategi Dalam Pemecahan. Indonesian Digital Journal of Mathematics and Education, 4(6), 358369.

Tarjiah, I. (2015). Pengembangan Model Pembelajaran Matematika Development of Mathematic Instructional Model for Student With Learning Disability At Inclusive. Jurnal Ilmiah visi pptk paudni, 10(2), 102-113.

Van Steenbrugge, H., Valcke, M., \& Desoete, A. (n.d.). Mathematics Learning Difficulties In Primary Education: Teachers' Professional Knowledge And The Use Of Commercially Available Learning Packages. 1-20.

Vincent, C. (2009). Ratio and proportion: Mapping the conceptual field. Natural Sciences, Master of, 83.

Walle, J. A. Van de. (2008). Matematika Sekolah Dasar dan Menengah: Pengembangan Pengajaran (Issue 101).

Yeni, E. M. (2015). Kesulitan Belajar Matematika Di Sekolah Dasar. Jupendas, 2(2), $1-10$. https://media.neliti.com/media/publications 171281-ID-kesulitan-belajar-matematikadi-sekolah.pdf

Yuwono, I., Kamil, M., Rahardja, D., \& Abdu, W. J. (2017). The Effect of Guidance and Counseling Programs on the Learning Processes of Visually Impaired High School Students. International Journal of Special Education, 32, 877-887. 
Yuwono, I., Rapisa, D. R., \& Damastuti, E. (2018). implementasi kurikulum fleksibel di sekolah penyelenggara pendidikan inklusif kota banjarmasin. 15(4), 2046-2069. https://doi.org/10.1109/COMST.2015.2457 491
Yuwono, I., Utomo, M., \& Pratomo Andi Widodo, A. (2018). Shadow Teacher Social Interaction Problem in SDN of Gadang 2 Banjarmasin. 147(Icsse 2017), 145-148. https://doi.org/10.2991/icsse-17.2018.34 